\title{
Effect of dietary lactose on salt-mediated changes in mineral metabolism and bone composition in the rat
}

\author{
BY C. SHORTT AND A. FLYNN \\ Department of Nutrition, University College, Cork, Republic of Ireland
}

(Received 28 September 1990 - Accepted 23 November 1990)

\begin{abstract}
The effects of salt (sodium chloride) supplementation of rat diets $(80 \mathrm{~g} / \mathrm{kg}$ diet), with or without lactose $(150 \mathrm{~g} / \mathrm{kg})$, were studied in weanling rats over $14 \mathrm{~d}$. Dietary salt increased water intake and reduced weight gain and food conversion efficiency, but these variables were unaffected by lactose. Saltsupplemented rats exhibited a three- to fivefold increase in urinary calcium excretion and a small increase in urinary magnesium and phosphorus excretion, irrespective of dietary lactose content. In addition, salt supplementation reduced plasma alkaline phosphatase $(E C$ 3. 1.3.1) activity. Lactose increased urinary $\mathrm{Ca}$ and $\mathrm{Mg}$ excretion and plasma $\mathrm{Ca}$ and $\mathrm{P}$ concentrations. Salt reduced tibia mass but not tibia mass expressed relative to body-weight, but neither variable was affected by lactose. Both tibia Mg content and concentration were reduced by salt but unaffected by lactose, and neither tibia $P$ content nor concentration was affected by salt or lactose. Tibia Ca content was reduced by salt but this was prevented by lactose. Tibia Ca concentration was unaffected by salt or lactose, although there was a reduction (not significant) in tibia $\mathrm{Ca}$ concentration in animals fed on the lactose-free diet. These results show that lactose had no independent effect on bone and that reduced accretion of bone mass and mineral content in rats fed on the high-salt diets was due, at least in part, to reduced growth. Failure to offset sodiuminduced hypercalciuria by a compensatory increase in net $\mathrm{Ca}$ absorption may have contributed to reduced bone $\mathrm{Ca}$ accretion. The protective effect of lactose against reduced bone $\mathrm{Ca}$ accretion may be due to increased $\mathrm{Ca}$ absorption.
\end{abstract}

Salt: Lactose : Calcium: Bone : Rat

There is a close relationship between urinary sodium and calcium excretion, and increased ingestion of sodium chloride increases urinary $\mathrm{Ca}$ excretion in experimental animals (Whiting \& Cole, 1986; Greger et al. 1987) and man (Law et al. 1988; Shortt et al. 1988). Na-induced hypercalciuria leads to reduced serum ionized Ca concentration and stimulates parathyroid hormone activity (Coe et al. 1975; Pernot et al. 1979; Breslau et al. 1982), which, in turn, may lead to increased bone resorption (Goulding \& Gold, 1988). In man, consumption of a high- $\mathrm{Na}$ diet is accompanied by increased serum 1,25-dihydroxycholecalciferol and enhanced $\mathrm{Ca}$ absorption (Breslau et al. 1982) which may protect against bone resorption. However, studies on rats have demonstrated that salt supplementation adversely affects Ca homeostasis and reduces bone Ca content (Goulding \& Gold, 1986; Goulding \& McIntosh, 1986).

Dietary lactose has been reported to increase serum Ca concentration in rats $(\mathrm{Au} \&$ Raisz, 1967; Miller et al. 1988) and to improve Ca retention in rats (Schaafsma \& Visser, 1980; Schaafsma et al. 1988) and in man (Condon et al. 1970), apparently by increasing the intestinal absorption of $\mathrm{Ca}$ by the non-vitamin $\mathrm{D}$-dependent pathway. In addition, consumption of lactose-containing diets has been shown to inhibit bone resorption in mice (Marie \& Travers, 1983) through a Ca-induced suppression of parathyroid hormone secretion. Thus, the present study was conducted to determine whether dietary lactose 
Table 1. Composition of the basal diet

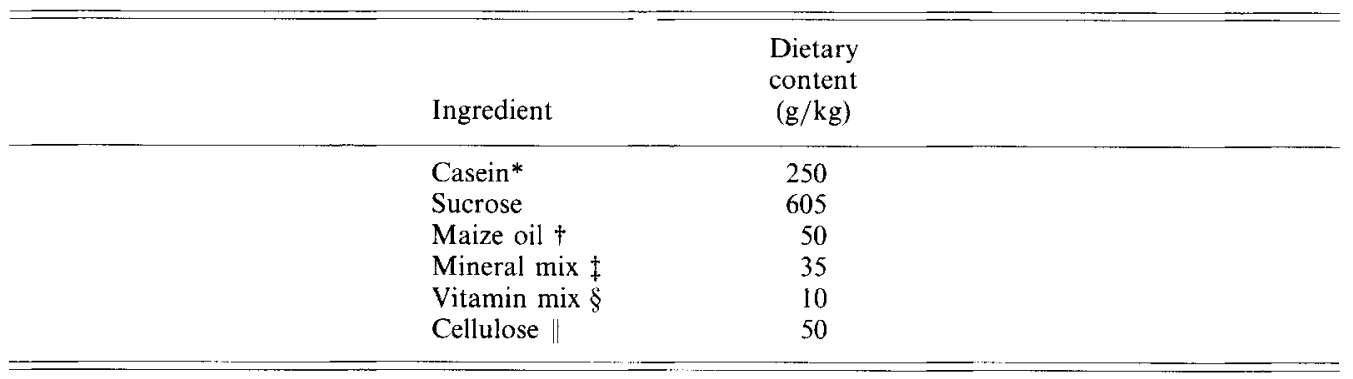

* Acid casein (870 g protein $/ \mathrm{kg}$ ); Kerry Co-Op, Listowel, Co. Kerry, Republic of Ireland.

$\dagger$ 'Mazola' Cooking Oil, CPC (UK) Ltd, Surrey, UK

\$ Based on American Institute of Nutrition (1977), supplied (g/kg diet): $\mathrm{CaHPO}_{4} 17 \cdot 5, \mathrm{NaCl} 2 \cdot 59$, $\mathrm{K}_{3} \mathrm{C}_{6} \mathrm{H}_{5} \mathrm{O}_{7} . \mathrm{H}_{2} \mathrm{O} 7 \cdot 7, \mathrm{~K}_{2} \mathrm{SO}_{4} 1 \cdot 82, \mathrm{MgO} 0.84, \mathrm{MnCO}_{3} 0 \cdot 122, \mathrm{C}_{6} \mathrm{H}_{5} \mathrm{O}_{7} \mathrm{Fe} .5 \mathrm{H}_{2} \mathrm{O} 0.21, \mathrm{ZnCO}_{3} 0.056, \mathrm{CuCO}_{3} 0.0105$, $\mathrm{KIO}_{3} 0 \cdot 00035, \mathrm{Na}_{2} \mathrm{SeO}_{3} 0 \cdot 00035, \mathrm{CrK}\left(\mathrm{SO}_{4}\right)_{2} .12 \mathrm{H}_{2} \mathrm{O} 0.01925$, sucrose $4 \cdot 13$.

$\S$ Based on American Institute of Nutrition (1977), supplied ( $\mathrm{mg} / \mathrm{kg}$ diet): thiamine hydrochloride 6, riboflavin 6, pyridoxine hydrochloride 7, nicotinic acid 30, calcium pantothenate 16, folic acid 2, D-biotin 0.2 , cyanocobalamin 0.01 , vitamin $\mathrm{K} 0.05$, vitamin A 1.5 (as retinol), vitamin D 0.025 , vitamin E 50 , and cellulose 9.8 $\mathrm{g} / \mathrm{kg}$ diet.

\| Commercial grade; FMC International, Cork, Republic of Ireland.

would counteract the effects of salt supplementation on $\mathrm{Ca}$ metabolism and bone composition in weanling rats.

\section{MATERIALS AND METHODS}

\section{Animals and diets}

Male weanling Wistar rats (approximately $95 \mathrm{~g}$ ), obtained from the Biological Services Unit, University College, Cork, were randomly divided into four groups of eight rats each. One group was given a basal diet (diet 1) as outlined in Table 1 while a second group was given a diet (diet 2) similar to the basal diet in every respect except that $150 \mathrm{~g} / \mathrm{kg}$ of the sucrose component was replaced by lactose. The third and fourth groups were fed on diets 1 and 2 supplemented with $\mathrm{NaCl}(80 \mathrm{~g} / \mathrm{kg}$ diet; diets 3 and 4 respectively).

Diets were prepared in a solidified form by incorporation $(1: 1, \mathrm{w} / \mathrm{w})$ into $30 \mathrm{~g}$ agar $/ 1$ solutions (Baker et al. 1979), stored in sealed trays at $4^{\circ}$ and cut as required for feeding. The $\mathrm{Ca}$ and phosphorus contents of the basal diet (by analysis, see p. 75 ) were 5.5 and $4.0 \mathrm{~g} / \mathrm{kg}$ dry weight respectively.

\section{Experimental methods}

A $14 \mathrm{~d}$ balance study was carried out, with rats housed individually in wire-bottom cages in which the trays were covered with stainless-steel wire mesh to separate faeces and leftover food from urine. Throughout the study food intake was controlled so that the energy intakes of all groups were similar. Fresh diet was provided daily and left-over food was recorded. Distilled drinking water was available ad lib. and consumption was monitored throughout the study. Urine was collected daily in containers primed with thymol and concentrated hydrochloric acid, made up to a known volume with distilled water, and stored at $4^{\circ}$ until mineral analyses were carried out. Faeces were collected daily (from day 2 to day 15 inclusive), pooled for each animal, and stored at $-20^{\circ}$ in air-tight containers.

On day 15 , rats were anaesthetized after an overnight fast by intraperitoneal injection of sodium pentobarbital solution $(1 \mathrm{ml} / \mathrm{kg}$ body-weight; Sagatal, May \& Baker Ltd, Dagenham, Essex). The abdomen was opened and a blood sample was obtained from the posterior vena cava and transferred to a heparinized vial. Plasma was obtained by 
centrifugation and stored frozen at $-20^{\circ}$. The tibia was removed from the right side of each animal, cleaned of adhering tissue, dried overnight at $100^{\circ}$, weighed and stored in sealed containers.

\section{Analytical methods}

Weighed diet samples and bones were digested in $10 \mathrm{ml}$ of a $2: 1(\mathrm{v} / \mathrm{v})$ mixture of concentrated nitric and perchloric acids on a hot plate (S. \& J. Juniper \& Co., Essex) until the sample colour resembled that of the reagent blank. Pooled faeces, for each animal, were dried overnight at $105^{\circ}$, mixed thoroughly and weighed portions (about $4 \mathrm{~g}$ ) were ashed at $550^{\circ}$ in a muffle furnace for $12 \mathrm{~h}$. The ash was dissolved in a mixture of concentrated hydrochloric and nitric acids $(1: 2, \mathrm{v} / \mathrm{v})$ and diluted appropriately for mineral analysis.

Dietary Na was determined by atomic absorption spectrophotometry (Model SP9; Pye Unicam Ltd, Cambridge). Ca in plasma, urine, faeces, diets and bones and magnesium in urine and bones were determined by atomic absorption spectrophotometry using lanthanum chloride ( $1 \mathrm{~g} / 1$; BDH Ltd, Poole, Dorset) as diluent. $\mathrm{P}$ was determined in serum, urine, bones and diet by the method of Weissman \& Pileggi (1974). Plasma alkaline phosphatase (EC 3.1.3.1) activity was determined according to the method of Bessey et al. (1946). Net intestinal absorption of $\mathrm{Ca}$ was calculated as the difference between dietary intake and faecal output, while retention was calculated as the difference between dietary intake and excretion in faeces and urine.

\section{Statistical analysis}

Results were subjected to two-way analysis of variance, variation being attributed to dietary lactose and salt (Snedecor \& Cochran, 1967). Means with their pooled standard errors are tabulated for each measurement with significant differences for dietary lactose and salt and lactose $\times$ salt interaction. Because of unequal variances, values for water intake and urinary $\mathrm{Ca}, \mathrm{Mg}$ and $\mathrm{P}$ were $\log _{10}$ transformed for statistical analysis and back transformed to geometric means, but pooled standard errors for these variates were left in the $\log$ scale.

\section{RESULTS}

As shown in Table 2, the mean food intake of all groups was similar. Mean body-weight gain and the food conversion efficiency were lower in the salt-supplemented than in nonsupplemented groups, irrespective of dietary lactose content, but were unaffected by lactose. Water consumption was about three times greater in the salt-supplemented compared with non-supplemented animals.

Salt-supplemented animals excreted significantly more $\mathrm{Ca}, \mathrm{Mg}$ and $\mathrm{P}$ in urine than nonsupplemented animals (Table 2). Lactose also increased urinary $\mathrm{Ca}$ and $\mathrm{Mg}$, but not $\mathrm{P}$, and the increase in urinary $\mathrm{Ca}$ was only observed at the lower salt intake. There was no significant effect of dietary salt or lactose on faecal $\mathrm{Ca}$ or on net $\mathrm{Ca}$ absorption or retention.

Mean plasma $\mathrm{Ca}$ and $\mathbf{P}$ concentrations of the basal and salt-supplemented groups (Table 3) were within the normal limits for rats (Mitruka \& Rawnsley, 1977) and both were increased by lactose supplementation regardless of salt intake. Plasma alkaline phosphatase activity was reduced by salt supplementation but was unaffected by lactose.

Tibia mass was lower in salt-supplemented than in non-supplemented animals, but when tibia mass was expressed relative to body-weight, dietary salt had no effect and lactose did not affect either of these variables (Table 3). Both content and concentration of $\mathrm{Mg}$ in tibia were reduced by salt supplementation irrespective of dietary lactose. A significant salt $\times$ lactose interaction occurred for tibia $\mathrm{Ca}$ content which was reduced by salt supplementation, but only with the lactose-free diet, while lactose had no independent effect on tibia Ca content. Tibia Ca concentration $(\mathrm{mg} / \mathrm{g}$ bone) was unaffected by dietary 
C. SHORTT AND A. FLYNN

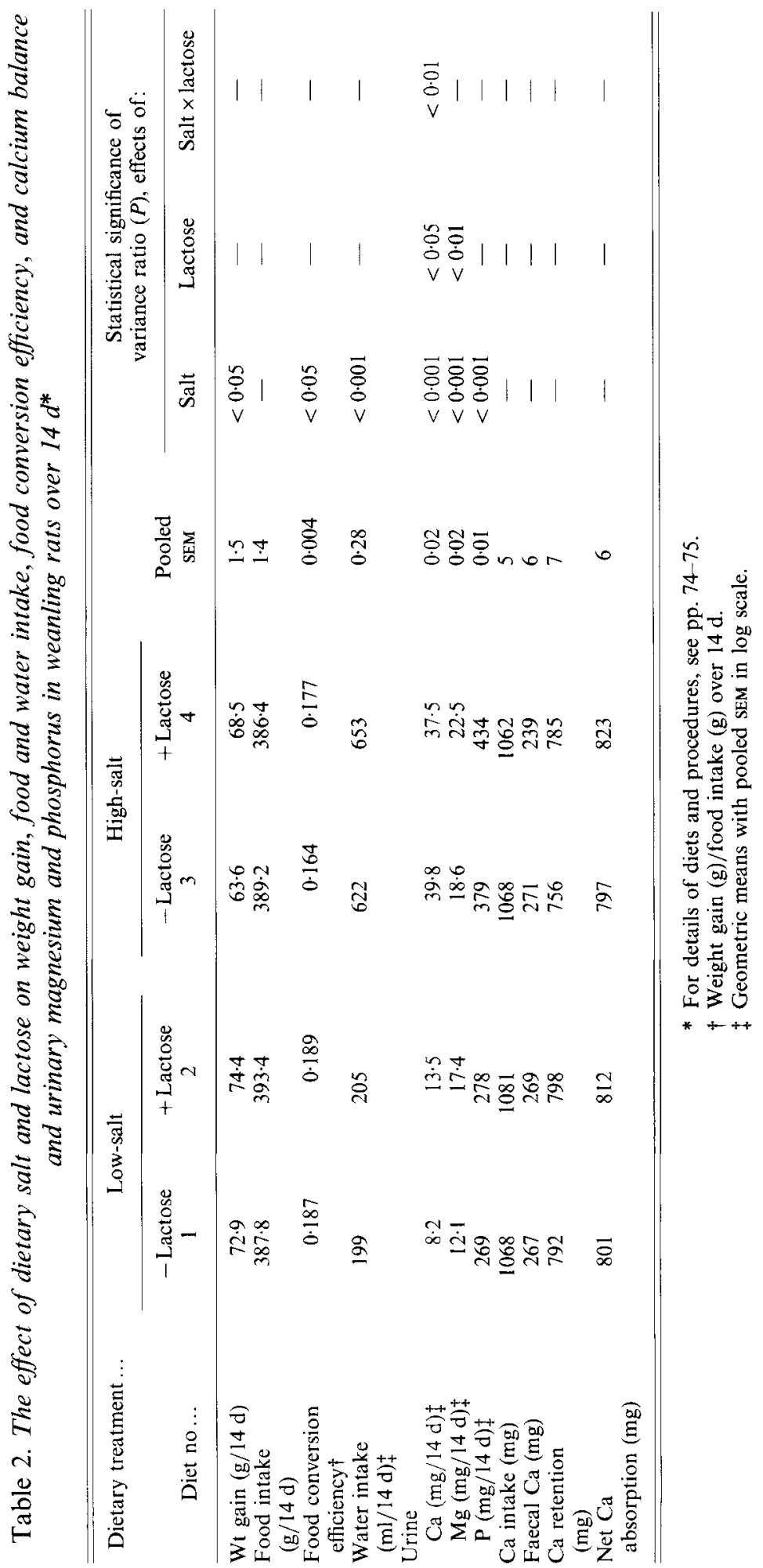




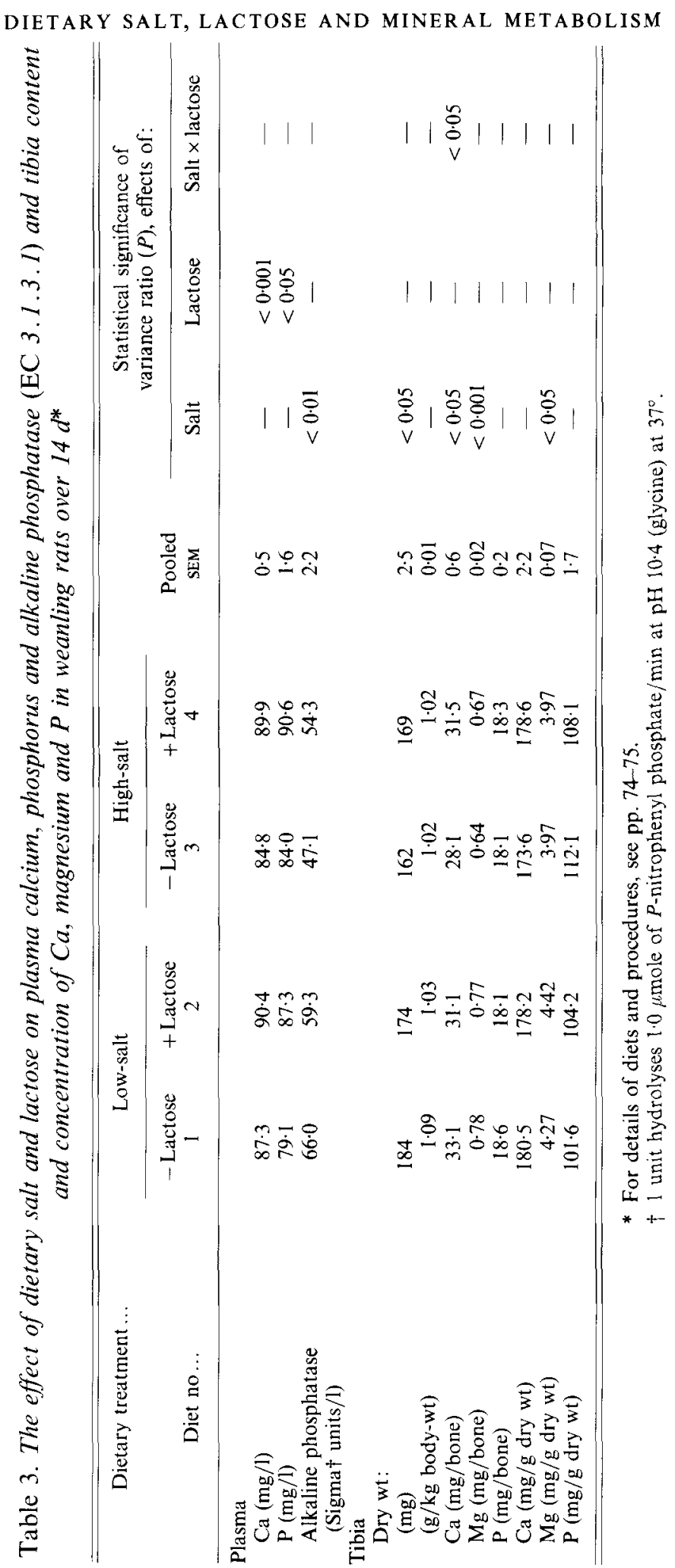


salt or lactose, although there was a decrease (not significant) in tibia Ca concentration with the lactose-free diet. Neither the content nor concentration of $\mathrm{P}$ in tibia was affected by dietary salt or lactose.

\section{DISCUSSION}

The results of the present study indicate that short-term intakes of salt supplements $(80$ $\mathrm{g} / \mathrm{kg}$ diet) significantly increased urinary $\mathrm{Ca}, \mathrm{Mg}$ and $\mathrm{P}$ excretion in rats irrespective of the lactose content of the diet. The effect of salt on urinary mineral excretion was most marked in the case of $\mathrm{Ca}$, with a three- to fivefold increase in animals given salt-supplemented compared with non-supplemented diets. These findings are consistent with the results of previous studies (Goulding \& Campbell, 1984; Goulding \& Gold, 1986). The dependence of urinary $\mathrm{Ca}$ excretion on urinary $\mathrm{Na}$ excretion has been attributed to the existence of linked or common re-absorption pathways for the ions in the convoluted portion of the renal proximal tubule and in the loop of Henle (Antoniou et al. 1969; McCarron et al. 1981).

Inclusion of lactose in the diet also increased urinary $\mathrm{Ca}$ and $\mathrm{Mg}$ excretion but had no significant effect on urinary $\mathrm{P}$ excretion. The effect of lactose on urinary $\mathrm{Ca}$ excretion was only observed at the lower salt intake. Previous reports have indicated that dietary lactose increases the urinary excretion of Ca (Schaafsma \& Visser, 1980; Schaafsma et al. 1988) and Mg (Marie \& Travers, 1983; Schaafsma et al. 1988), but has no effect on urinary P excretion (Schaafsma \& Visser, 1980).

Plasma $\mathrm{Ca}$ concentration was unaffected by dietary salt but was increased by lactose. Dietary lactose has previously been shown to increase serum Ca concentration (Marie \& Travers, 1983; Miller et al. 1988) and to improve Ca retention (Forbes, 1964; Miller et al. 1988; Schaafsma et al. 1988) in animals, apparently by increasing the intestinal absorption of Ca. Plasma $\mathrm{P}$ concentration was also significantly increased by lactose, in agreement with previous studies which showed that diets containing lactose at 100 (Marie \& Travers, 1983) or 300 (Debiec \& Lorenc, 1988) g/kg diet increased plasma P concentration in animals.

Salt supplementation reduced plasma alkaline phosphatase activity, which is consistent with a reduced rate of $\mathrm{Ca}$ accretion in bone (Klein et al. 1964), although plasma alkaline phosphatase activity is not regarded as a sensitive marker of the rate of bone formation (Taylor et al. 1988). Dietary lactose had no independent effect on plasma alkaline phosphatase activity in the present study, similar to the findings of Schaafsma \& Visser (1980).

Tibia mass was reduced by salt supplementation but was unaffected by lactose. However, when expressed on a body-weight basis, there was no effect of salt on tibia mass, suggesting that the effect of salt was due, at least in part, to lower body-weight gain in saltsupplemented animals. Tibia $\mathrm{Ca}$ and $\mathrm{Mg}$, but not $\mathrm{P}$, contents were reduced by dietary salt. Salt also reduced tibia $\mathrm{Mg}$ concentration but not tibia $\mathrm{Ca}$ concentration, although there was a reduction (not significant) in bone $\mathrm{Ca}$ concentration in rats fed on the lactose-free diet. There is considerable evidence that salt supplementation $(80 \mathrm{~g} / \mathrm{kg}$ diet $)$ for periods of $10 \mathrm{~d}-12$ weeks reduces bone mass and Ca content in young and adult rats consuming diets either deficient (Goulding, $1980 a, b$; Goulding \& Campbell, 1982, 1983; Goulding \& Gold, 1986) or adequate (Goulding \& Campbell, 1984) in Ca, although some studies have failed to show this (Goulding, 1980 b; Goulding \& Gold, 1988).

It has been suggested that Na-induced hypercalciuria leads to a reduction in serum ionized $\mathrm{Ca}$ which, in turn, stimulates the secretion of parathyroid hormone (Goulding et al. 1986). While serum ionized $\mathrm{Ca}$ was not measured in the present study, there was no significant reduction in plasma $\mathrm{Ca}$ in the salt-supplemented animals, suggesting that $\mathrm{Ca}$ 
homeostasis was maintained despite the $\mathrm{Na}$-induced hypercalciuria. An increase in urinary $\mathrm{Ca}$ excretion in the absence of a compensatory increase in $\mathrm{Ca}$ absorption, or a reduction in endogenous $\mathrm{Ca}$ losses, may result in reduced $\mathrm{Ca}$ retention and lead to bone loss.

The literature is conflicting in relation to changes in $\mathrm{Ca}$ absorption during salt supplementation in rats. Net $\mathrm{Ca}$ absorption was not increased in salt-supplemented $(80 \mathrm{~g} / \mathrm{kg}$ diet) rats fed on diets deficient (Goulding \& Campbell, 1983; Goulding \& McIntosh, 1986) or adequate (Goulding \& Campbell, 1984) in Ca. In contrast, Goulding $\&$ Gold (1986) reported increased net $\mathrm{Ca}$ absorption in salt-supplemented rats fed on a $\mathrm{Ca}-$ deficient diet for 12 weeks.

In the present study, salt supplementation increased urinary Ca excretion by an amount equivalent to only $3-4 \%$ of the total $\mathrm{Ca}$ absorbed and retained over the 2 -week study period. While the precision of the balance method does not permit determination of whether $\mathrm{Ca}$ absorption or retention were altered by such an amount, it is clear from the lower tibia $\mathrm{Ca}$ content of the animals given lactose-free, salt-supplemented diets that homeostasis was achieved, at least in part, at the expense of bone $\mathrm{Ca}$.

Evidence in humans suggests that healthy individuals respond to $\mathrm{Na}$-induced calciuria by a parathyroid-hormone-mediated increase in intestinal Ca absorption (Meyer et al. 1976; Breslau et al. 1982). However, this adaptive mechanism does not appear to function in all individuals, e.g. those with impaired parathyroid function (Breslau et al. 1982), postmenopausal women with osteoporosis (Breslau et al. 1985), as well as in some healthy postmenopausal women (McParland et al. 1989), and even in those individuals who appear to adapt, the increase in net $\mathrm{Ca}$ absorption may not be sufficient to offset the increase in urinary $\mathrm{Ca}$ losses (Breslau et al. 1982). Furthermore, the capacity for such adaptation may be limited by low dietary $\mathrm{Ca}$ intakes, poor vitamin $\mathrm{D}$ status, impaired renal function or poor intestinal Ca absorption (Shortt \& Flynn, 1990). Nordin \& Polley (1987) reported that bone density was negatively correlated with urinary $\mathrm{Na}$ excretion in post-menopausal women. However, moderate dietary salt restriction did not reduce the rate of bone loss over a 9-month period compared with unrestricted control subjects.

Although lactose had no independent effect on tibia mass or mineral content, a significant salt $\times$ lactose interaction occurred for tibia $\mathrm{Ca}$ content, indicating that salt supplementation did not affect bone Ca content in animals fed on the lactose-containing diets. The finding that lactose protected against the decrease in tibia Ca content, but not against the decrease in body-weight gain or tibia mass or Mg content, indicates that lactose selectively protects salt-supplemented animals against reduced $\mathrm{Ca}$ accretion in bone. This protective effect of lactose on bone $\mathrm{Ca}$ is consistent with the findings of Marie \& Travers (1983) who reported that dietary lactose increased bone calcification rate and inhibited bone resorption in X-linked hypophosphataemic mice, who are particularly prone to bone resorption.

It seems likely that the protection by lactose of bone $\mathrm{Ca}$ against the effect of high salt intake may be due to increased $\mathrm{Ca}$ absorption as indicated by increased plasma $\mathrm{Ca}$ concentration and increased urinary $\mathrm{Ca}$ excretion. While no effect of lactose on net $\mathrm{Ca}$ absorption was observed in the present study, the precision of the balance method is not sufficient to detect the relatively small changes in $\mathrm{Ca}$ absorption which may have occurred. Increased $\mathrm{Ca}$ absorption would normalize plasma $\mathrm{Ca}$ which, in turn, would reduce the stimulus for parathyroid hormone secretion and for parathyroid-hormone stimulated bone resorption.

\section{REFERENCES}

American Institute of Nutrition (1977). Ad Hoc Committee on Standards for Nutritional Studies. Report of the Committee. Journal of Nutrition 107, 1340-1348. 
Antoniou, L., Eisner, G., Slotkoff, L. \& Lilienfield, L. (1969). Relationship between sodium and calcium transport in the kidney. Journal of Laboratory and Clinical Medicine 74, 410-420.

Au, W. Y. \& Raisz, L. G. (1967). Restoration of parathyroid responsiveness in vitamin D-deficient rats by parenteral calcium or dietary lactose. Journal of Clinical Investigation 46, 1572-1578.

Baker, H. J., Lindsey, R. J. \& Weisbroth, H. (1979). Housing to control research variables. In The Laboratory Rat, vol. I, pp. 169-187 [H. J. Baker, R. J. Lindsey and H. Weisbroth, editors]. London: Academic Press.

Bessey, O. A., Lowry, O. H. \& Brock, M. J. (1946). A method for the rapid determination of alkaline phosphatase with five cubic millimeters of serum. Journal of Biological Chemistry 164, 321- 332.

Breslau, N. A., McGuire, J. L., Zerwekh, J. E. \& Pak, C. Y. C. (1982). The role of dietary sodium in renal excretion and intestinal absorption of calcium and in vitamin D metabolism. Journal of Clinical Endocrinology and Metabolism 55, 369-373.

Breslau, N. A., Sakhaee, K. \& Pak, C. Y. C. (1985). Impaired adaptation to salt-induced urinary calcium losses in postmenopausal osteoporosis. Transactions of the Association of American Physicians 98, 107-115.

Coe, F. L., Firpo, J.J., Hollandsworth, D. L., Segil, L., Canterbury, J. M. \& Reiss, E. (1975). Effects of acute and chronic metabolic acidosis on serum immunoreactive parathyroid hormone in man. Kidney International 8 , $262-273$.

Condon, J. R., Nassim, J. R., Millard, F. J. C., Hilbe, A. \& Stainthorpe, E. M. (1970). Calcium and phosphorus metabolism in relation to lactose tolerance. Lancet $\mathbf{i}, 1027-1029$.

Debiec, H. \& Lorenc, R. (1988). Influence of lactose on phosphate metabolism in rats. British Journal of Nutrition 59, 87-92.

Forbes, R. M. (1964). Mineral utilization in the rat. III. Effects of calcium, phosphorus, lactose and source of protein in zinc-deficient and in zinc-adequate diets. Journal of Nutrition $\mathbf{8 3}, 225-233$.

Goulding, A. $(1980 a)$. Effects of sodium chloride supplements on tibial calcium content in rats taking a lowcalcium diet with a moderate or a high protein intake. Proceedings of the University of Otago Medical School 58, $13-14$.

Goulding, A. (1980 b). Effects of dietary $\mathrm{NaCl}$ supplements on parathyroid function, bone turnover and bone composition in rats taking restricted amounts of calcium. Mineral Electrolyte Metabolism 4, 203-208.

Goulding, A. \& Campbell, D. R. (1982). Generalized skeletal loss of calcium induced by oral sodium chloride supplements in adult oophorectomized rats consuming a low-calcium diet. Proceedings of the University of Otago Medical School 60, 3-4.

Goulding, A. \& Campbell, D. R. (1983). Dietary NaCl loads promote calciuria and bone loss in adult oophorectomized rats consuming a low calcium diet. Journal of Nutrition 113, 1409-1414.

Goulding, A. \& Campbell, D. R. (1984). Effects of oral loads of sodium chloride on bone composition in growing rats consuming ample dietary calcium. Mineral Electrolyte Metabolism 10, 58-62.

Goulding, A., Everitt, H., Cooney, J. \& Spears, G. (1986). Sodium and Osteoporosis. In Recent Advances in Clinical Nutrition, vol. 2, pp. 99-108 [M. Wahlquist and A. Truswell, editors]. London: John Libbey.

Goulding, A. \& Gold, E. (1986). Effects of dietary sodium chloride loading on parathyroid function, 1,25dihydroxy vitamin $\mathrm{D}$, calcium balance, and bone metabolism in female rats during chronic prednisolone administration. Endocrinology 119, 2148-2154.

Goulding, A. \& Gold, E. (1988). Effects of dietary $\mathrm{NaCl}$ supplementation on bone synthesis of hydroxyproline, urinary hydroxyproline excretion and bone ${ }^{45} \mathrm{Ca}$ uptake in the rat. Hormone and Metabolic Research 20 , 734-745,

Goulding, A. \& McIntosh, J. (1986). Effects of $\mathrm{NaCl}$ on calcium balance, parathyroid function, and hydroxyproline excretion in prednisolone-treated rats consuming low calcium diet. Journal of Nutrition 116, 1037-1044.

Greger, J. L., Krashoc, C. L. \& Krzykowski, C. E. (1987). Calcium, sodium and chloride interaction in rats. Nutrition Research 7, 401-412.

Klein, L., Lafferty, F. W., Pearson, O. H. \& Curtiss, P. H. (1964). Correlation of urinary hydroxyproline, serum alkaline phosphatase and skeletal calcium turnover. Metabolism 13, 272-284.

Law, L. K., Swaminathan, R. \& Donnan, S. P. B. (1988). Relationship between sodium excretion and calcium excretion in healthy subjects. Medical Science Research 16, 643.

McCarron, D. A., Rankin, L. I., Bennett, W. M., Krutzik, S., McClung, M. R. \& Luft, F. C. (1981). Urinary calcium excretion at extremes of sodium intake in normal man. American Journal of Nephrology 1, 84-90

McParland, B. E., Goulding, A. \& Campbell, A. J. (1989). Dietary salt affects biochemical markers of resorption and formation of bone in elderly women. British Medical Journal 299, 834-835.

Marie, P. J. \& Travers, R. (1983). Effects of magnesium and lactose supplementation on bone metabolism in the X-linked hypophosphatemic mouse. Metabolism 32, 165-171.

Meyer, W. J., Transbol, I., Bartter, F. C. \& Delea, C. (1976). Control of calcium absorption. Effect of sodium chloride loading and depletion. Metabolism 25, 989-993.

Miller, S. C., Miller, M. A. \& Omura, T. H. (1988). Dietary lactose improves endochondral growth and bone development and mineralization in rats fed a vitamin D-deficient diet. Journal of Nutrition 118, 72-77.

Mitruka, B. M. \& Rawnsley, H. M. (1977). Clinical biochemistry. In Clinical, Biochemical and Haematological Reference Values in Normal Experimental Animals, Section 5, pp. 117-129 [B. M. Mitruka and H. M. Rawnsley, editors]. New York: Masson Publishing. 
Nordin, B. E. C. \& Polley, K. J. (1987). Metabolic consequences of the menopause. Calcified Tissues International 41, S1-S59.

Pernot, F., Berthelot, A., Schleiffer, R. \& Gairard, A. (1979). Ionized serum calcium, urinary cAMP and immunoreactive PTH after DOCA + NaCl treatment in the rat. Mineral Electrolyte Metabolism 2, 258.

Schaafsma, G., Dekker, P. R. \& de Waard, H. (1988). Nutritional aspects of yogurt. 2. Biovavailability of essential minerals and trace elements. Netherlands Milk and Dairy Journal 42, 135-146.

Schaafsma, G. \& Visser, R. (1980). Nutritional interrelationships between calcium, phosphorus and lactose in rats. Journal of Nutrition 110, 1101-1111.

Shortt, C. \& Flynn, A. (1990). The sodium-calcium interrelationship with particular reference to osteoporosis. Nutrition Research Reviews 3, 101-115.

Shortt, C., Madden, A., Flynn, A. \& Morrissey, P. A. (1988). The influence of dietary sodium chloride intake on urinary calcium on selected Irish individuals. European Journal of Clinical Nutrition 42, 595-603.

Snedecor, G. W. \& Cochran, W. G. (1967). Statistical Methods. Ames, Iowa: Iowa State University Press.

Taylor, A. K., Lundy, M. W., Libanati, C. R. \& Baylink, D. J. (1988). Diagnostic tests for metabolic bone and mineral disorders. In Metabolic Bone and Mineral Disorders, pp. 33-62 [S. C. Manolagas and J. M. Olefsky, editors]. New York: Churchill Livingstone.

Weissman, N. \& Pileggi, V. J. (1974). Inorganic ions. In Clinical Chemistry: Principles and Technics, pp. 639-754 [R. J. Henry, D. C. Cannon and J. W. Winkelman, editors]. Maryland: Harper \& Row.

Whiting, S. J. \& Cole, D. E. (1986). Effect of dietary anion composition on acid-induced hypercalciuria in the adult rat. Journal of Nutrition 116, 388-394. 